\title{
Influence of Age on Duodenal Brush Border Membrane and Specific Activities of Brush Border Membrane Enzymes in Wistar Rats
}

\author{
InSurk J ANG'), KeunKi J UNG2), and J ungSik $\mathrm{CHO}^{3)}$
}

\begin{abstract}
1)Department of Animal Science, College of Agriculture, Chinju National University, Chilam-dong, 150, Chinju, Kyung-Nam 600-758, 2)Department of Animal Science, College of Natural Resources, YeungNam University, Dae-dong, 214, Kyunsan, Kyung-Pook 712-749, and ${ }^{3}$ Laboratory Animal Resources, National Institute of Toxicological Research, KFDA, 5-Nokbundong, Eunpyung-ku, Seoul 122-020, Korea
\end{abstract}

\begin{abstract}
To examine age-related changes in the morphology of intestinal brush border membrane (BBM; microvilli) and specific activities of intestinal BBM enzymes including alkaline phosphatase (ALP), $\gamma$-glutamyl transpeptidase $(\gamma-G T)$, and disacchridase, four groups of Wistar rats were sacrificed at $2.5 \mathrm{wk}, 5 \mathrm{wk}, 5 \mathrm{mon}$ and 23 mon. In an electron microscopic examination, morphologically a less dense BBM structure in the duodenum of rats aged 23 mon was observed than that of rats aged 5 mon. Specific activity of ALP in the duodenum from 5-mon-old rats was significantly higher than from rats aged $2.5 \mathrm{wk}$ and 23 mon. The mucosal tissues from 5-wk-old rats had significantly higher specific activity of $\gamma$-GT than did tissues from the other ages. In sucrase and maltase specific activities, 5mon-old rats had higher activities of these enzymes than other age groups, especially 2.5wk- and 23-mon-old rats. There was also a significant effect of site on intestinal BBM enzyme activities in post-weanling rats. Regional gradients of ALP and $\gamma$-GT along the entire small intestine (duodenum>jejunum>ileum) were remarkable. Disaccharidase activities peaked in the jejunum and declined toward both the duodenum and ileum. Taken together the result obtained here suggested that 5-mon-old rats had the most elevated intestinal function. This result also strongly indicated that the structure of the intestinal BBM and development of intestinal BBM enzymes in Wistar rats were markedly influenced by age during the postnatal period.
\end{abstract}

Key words: age, ALP, disaccharidase, $\gamma-G T$, microvilli

\section{Introduction}

When rodents are exposed to many environmental stimuli, the responses vary according to age, strain, gender, disease, diets, physiological status, and the site of the organs $[4,13,23,31]$. Among various organs, the epithelial cells lining the lumen of the gut are the first membrane barrier between the outside environment and the inside circulator in response to external and internal stimuli. The major mechanism associated with absorp-

(Received 18 October 1999 / Accepted 15 May 2000)

Address corresponding: InSurk Jang, Department of Animal Science, College of Agriculture, Chinju National University, Chilam-dong, 150, Chinju, Kyung-Nam, 660-758, Korea 
tive epithelial cells is the transport of nutrients from the small intestine into the circulatory system [2]. During this process, many adaptive responses occur in intestinal absorptive cells under various circumstances.

The effect of age on regulation of intestinal absorptive cells has not yet been addressed. The absorptive cells that line the gut seem to be an object of interest in studying cellular aging because newborn cells undergo mitosis at very short intervals throughout life. Although some studies of intestine aging in mice reported that intestinal nutrient transport was independent of age [10], several studies suggests that old age is associated with impaired intestinal adaptive responses to changes in diet, ingestion of xenobiotics, and the incidence of metabolic disease $[9,13]$.

It is reasonable to investigate the structure of the duodenal brush border membrane (BBM) to distinguish the effect of age on intestinal functions, since major nutrient transport processes occur in this site. And BBM enzymes such as alkaline phosphatase, $\gamma$-glutamyl transpeptidase and disaccharidase are important constituents of the microvillous membrane [8]. Noticeable loss of BBM enzymes in aged animals suggests the possibility of serious deterioration of the membrane, digestion of carbohydrate, and absorption of all nutrients. In spite of evidence that age affects on absorptive functions in the small intestine, a systemic approach to the effect of age on the morphology of intestinal BBM and BBM enzymes during the postnatal period is still lacking. In order to examine whether age would influence intestinal BBM function during the postnatal period, we sought to determine age-associated changes in the structure of intestinal BBM and profiles of intestinal BBM hydrolases in Wistar rats aged $2.5 \mathrm{wk}, 5 \mathrm{wk}, 5 \mathrm{mon}$ and 23 mon.

\section{Materials and Methods}

Animals and tissue harvesting: Male Wistar rats were purchased from Chars River, Japan and kept in a barrier facility at regulated temperature $\left(23 \pm 1{ }^{\circ} \mathrm{C}\right)$ and on a light/dark cycle (light on 07:00-19:00). All the rats were given free access to commercial chow based upon the NIH-07 formula and their feed and body weight were monitored once a week. To harvest the small intestine, eight rats per group were chosen at the age of 2.5 wk (18 days; just before weanling), 5 wk, 5 mon and 23 mon. The small intestine was removed at the pylorus and at the ilio-cecal valve immediately after anesthetizing with $\mathrm{CO}_{2}$ gas. The harvested small intestine was perfused with ice-cold saline and gently squeezed to remove remaining digesta. Then total intestinal weight and length were measured. Ten percent of the proximal region was designated as the duodenum, the next $45 \%$ as the jejunum, and the rest of the distal region as the ileum. The length of each segment was rinsed in three successive baths containing mannitol buffer $\left(5 \mathrm{mM} \mathrm{MgCl}_{2}, 150 \mathrm{mM}\right.$ mannitol, $10 \mathrm{mM}$ Tris base, $30 \mathrm{mM}$ succinate, $5 \mathrm{mM} \mathrm{K}_{2} \mathrm{HPO}_{4}$ and $1 \mathrm{mM}$ $\mathrm{MnCl}_{2} ; \mathrm{pH}$ 7.4). Immediately after washing, the intestinal segments were replaced in an aluminum pan on a bed of ice. The mucosal surface was removed by gentle scraping with a glass slide to obtain epithelial cells. Residual fat and digesta were removed from the harvested mucosal tissues by resuspension twice in equal volumes of mannitol buffer followed each time by centrifugation at $10,000 \times \mathrm{g}$ at $4^{\circ} \mathrm{C}$ for $15 \mathrm{~min}$. The harvested mucosa from each section was weighed and homogenized with 1:6 volumes of mannitol buffer in a Teflon-glass homogenizer. The aliquots were stored at $-70^{\circ} \mathrm{C}$ for later assay of enzyme activities.

Electron microscopy: To examine the morphology of the duodenal BBM, male Wistar rats $(\mathrm{n}=2)$ aged 5 mon and 23 mon were anesthetized with sodium pentobarbital and perfused through the left ventricle of the heart with saline, followed by $2 \%$ paraformaldehyde and 3\% glutaraldehyde in $0.1 \mathrm{M}$ phosphate buffer for $20 \mathrm{~min}$. The dissected section of the duodenum located exactly $10 \mathrm{~cm}$ from pylorus valve was trimmed to $1 \mathrm{~mm}^{3}$, soaked for $3 \mathrm{hr}$, then immersed in $0.1 \mathrm{M}$ phosphate buffer overnight. A specimen fixed with $1 \%$ osmium tetroxide was dehydrated through ethanol and embedded in Epon-arlidite embedding medium in an automatic oven at $24^{\circ} \mathrm{C}$ for $24 \mathrm{hr}$. The embedded specimen was cut into $60 \mathrm{~nm}$ sections with an ultramicrotome. Thin sections were stained with uranyl acetate and lead citrate, and then examined by electron microscopy (CM12/ STEM, Philips, Netherland).

Determination of enzyme activities: To determine specific activities of intestinal BBM enzymes, the homogenized tissue was diluted 2 times with $2 \%$ triton X-100 to separate enzymes from the membrane fraction. Alkaline phosphatase (ALP: E.C.3.1.3.1) was assayed with a Sigma Diagnostic Assay Kit (Procedure No, 245) and an ELISA (Molecular Device) to deter- 
mine the continuous increase in absorbance at $405 \mathrm{~nm}$. Specific activity was expressed as the p-nitrophenol amount liberated per $\mathrm{mg}$ of protein. $\gamma$-Glutamyl transpeptidase ( $\gamma$-GT, E.C. 2.3.2.2) activity was determined by the colorimeteric method with a Sigma Diagnostic Assay kit at $450 \mathrm{~nm}$. Lactase, sucrase, and maltase activities were determined by the modified procedure of Dahlgvist [5]. The end product, glucose was measured by an ELISA at $450 \mathrm{~nm}$. The bicinchronic acid (BCA protein assay) method was adapted to microtiter plate to determine the protein concentration.

Statistical analysis: Effect of age or both age and the intestinal site were analyzed by ANOVA. When the age or site effect was significant at $\mathrm{P}<0.05$, Tukey's test was applied to identify significant differences among groups. The level of probability for statistical difference was established at $\mathrm{P}<0.05$.

\section{Results}

Quantitative changes in body weight and the intestine: Table 1 presents changes in body weight, intestine length, intestine weight, and wet mucosal weight of epithelial cells obtained from Wistar rats at various ages. Throughout experiment, rats aged 23 mon had the heaviest body weight and greatest intestine length. As age increased, intestine weight was also significantly increased until 5-mon-old, but after that the intestine weight of 5-mon-old rats did not differ from that of 23- mon-old rats. When comparing the wet mucosal weight of intestine sections, duodenal and ileal mucosal weights of 23-mon-old rats were the lowest in the post-weanling rats. In a comparison of wet mucosal weight per $\mathrm{cm}$ along the small intestine, 23-mon-old rats also have noticeably decreased amounts.

Morphological changes in duodenal absorptive cells: Electron micrographs of the microvilli structure in the duodenum of rats aged 5 mon and 23 mon are compared in Fig. 1 (A and B). Electron microscopic examination of the BBM in the duodenum revealed that 23-mon-old rats apparently had less dense BBM architecture than rats aged 5 mon, but microvillous height was similar in all age groups we tested.

Specific activities of intestinal BBM enzymes: Duodenal ALP specific activity of 5-mon-old rats was the highest in all age groups tested (Fig. 2A). The ileum of 5-wk-old rats exhibited significantly higher ALP specific activity than the ileum of the other groups. In contrast, $2.5 \mathrm{wk}$ and 23-mon-old rats had lower specific activity of ALP along the entire intestine. When comparing intestinal sites, the regional gradient along the small intestine of all age groups was remarkable. Specific activity of ALP was approximately 500\% greater in the duodenum than in the ileum. The specific activity of $\gamma$-GT in the duodenum of rats aged 5 wk was much higher than in any other age group (Fig. 2B). As regards the intestinal site, $\gamma$-GT specific activity was about an order of magnitite higher in the

Table 1. Age-related changes in intestinal weight, length, and wet mucosal weight in Wistar rats aged $2.5 \mathrm{wk}, 5 \mathrm{wk}, 5$ mon and 23 mon

\begin{tabular}{|c|c|c|c|c|}
\hline \multirow[t]{2}{*}{ Item } & \multicolumn{4}{|c|}{ Age } \\
\hline & $2.5 \mathrm{wk}$ & $5 \mathrm{wk}$ & 5 mon & 23 mon \\
\hline Body weight (g) & $45.1 \pm 2.32^{\mathrm{a}}$ & $143.2 \pm 9.11^{\mathrm{b}}$ & $341.1 \pm 19.0^{\mathrm{c}}$ & $792.2 \pm 58.2^{\mathrm{e}}$ \\
\hline Intestine length $(\mathrm{cm})$ & $57.0 \pm 1.69^{a}$ & $90.4 \pm 4.35^{b}$ & $107.0 \pm 4.84^{\mathrm{c}}$ & $121.5 \pm 6.02^{\mathrm{d}}$ \\
\hline Intestine weight (g) & $1.47 \pm 0.14^{\mathrm{a}}$ & $4.80 \pm 0.34^{\mathrm{b}}$ & $7.35 \pm 0.42^{c}$ & $8.20 \pm 0.72^{c}$ \\
\hline \multicolumn{5}{|c|}{ Wet mucosa weight ${ }^{1}(\mathrm{~g})$} \\
\hline Total & $0.55 \pm 0.08^{\mathrm{a}}$ & $1.32 \pm 0.20^{\mathrm{bc}}$ & $1.42 \pm 0.25^{\mathrm{c}}$ & $0.97 \pm 0.16^{\mathrm{b}}$ \\
\hline Duodenum & $0.16 \pm 0.02^{\mathrm{a}}$ & $0.33 \pm 0.10^{\mathrm{b}}$ & $0.32 \pm 0.07^{b}$ & $0.21 \pm 0.03^{\mathrm{a}}$ \\
\hline Jejunum & $0.20 \pm 0.04^{a}$ & $0.52 \pm 0.09^{b}$ & $0.62 \pm 0.15^{b}$ & $0.58 \pm 0.17^{b}$ \\
\hline Ileum & $0.19 \pm 0.04^{a}$ & $0.47 \pm 0.13^{b}$ & $0.48 \pm 0.08^{b}$ & $0.18 \pm 0.08^{a}$ \\
\hline \multicolumn{5}{|l|}{ Mucosa weight/length } \\
\hline$(\mathrm{mg} / \mathrm{cm})$ & $9.65 \pm 1.48^{\mathrm{a}}$ & $14.60 \pm 2.30^{\mathrm{b}}$ & $13.27 \pm 2.38^{b}$ & $7.98 \pm 1.77^{\mathrm{a}}$ \\
\hline
\end{tabular}

${ }^{1}$ Wet mucosa weight was measured after removing the residual fat, debris of connective tissue, and extra moisture by centrifugation at $10,000 \times \mathrm{g}$.

a,b,c,d,e Means with different letters in the same row are significantly different at $\mathrm{P}<0.05$. Each value denotes mean \pm S.D for 8 rats in each group. 

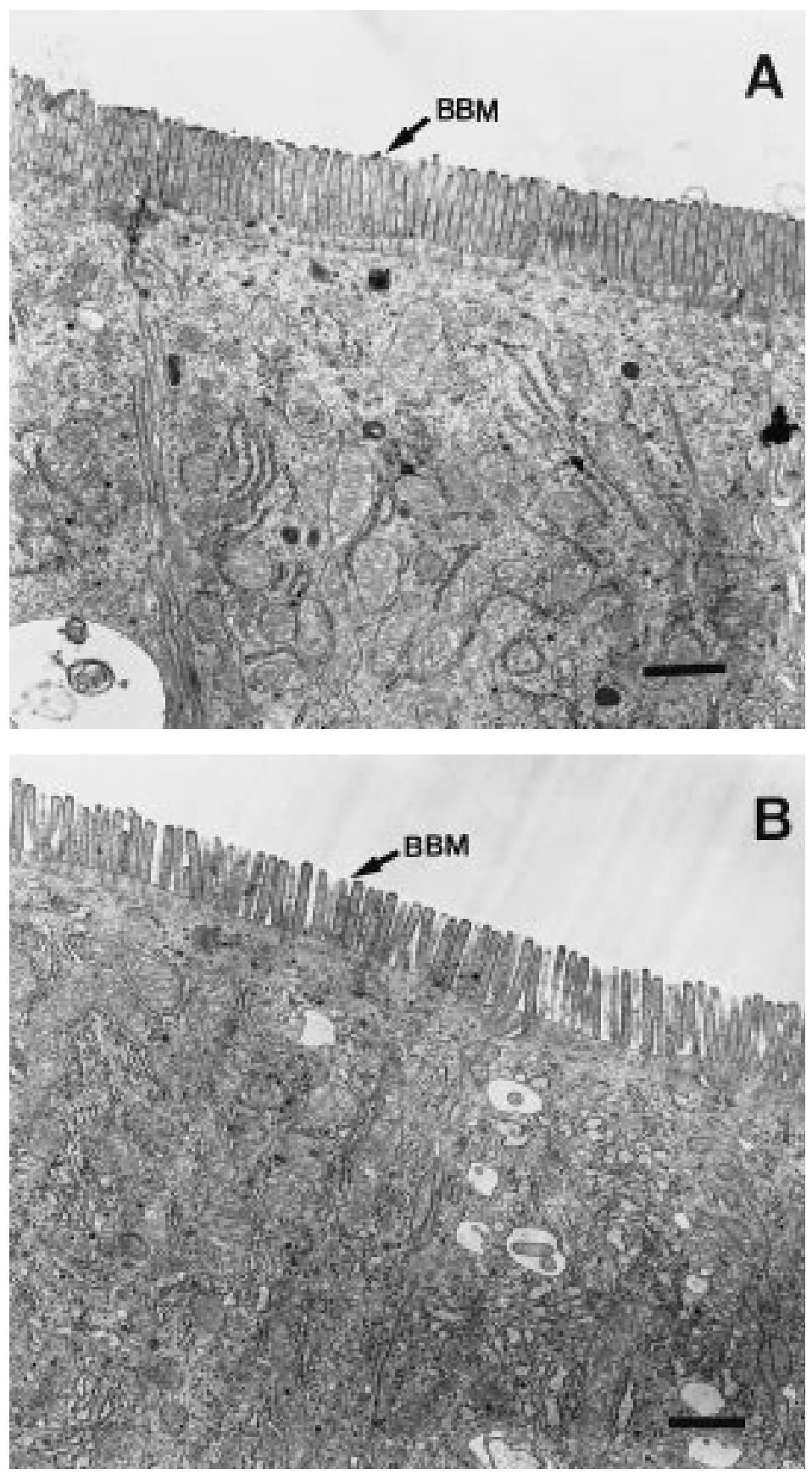

Fig. 1. Age-related changes in duodenal brush border membrane (BBM) of absorptive cells in the small intestine of Wistar rats aged 5 mon (A) and 23 mon (B). Brush border membrane (arrowhead) is presented at the picture; bar $=1 \mu \mathrm{m}$.

duodenum than in more distal regions. Sucrase specific activity of mucosal tissue in the jejunum of 5-mon-old rats was about $100 \%$ higher than that of 23mon-old rats (Fig. 3A). As regards the intestinal region, sucrase activity peaked in the jejunum and declined toward both the duodenum and ileum. Significantly lower specific activity of maltase in the small intestine of 23 mon-old rats was also observed compared with that of 5-mon-old rats (Fig. 3B). As regards site, the jejunum possessed the highest maltase activity along 
$\mathbf{A}$

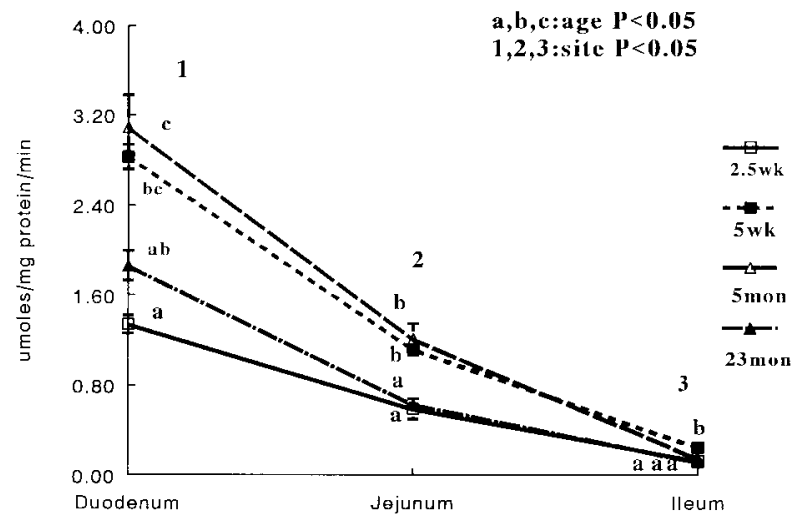

B

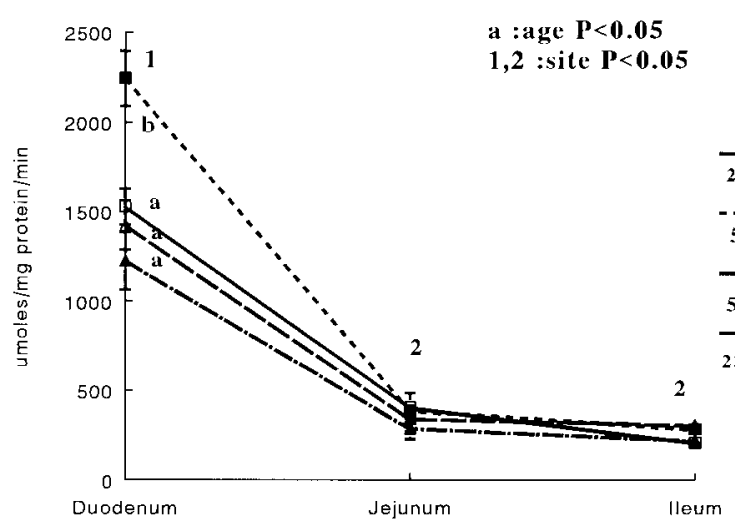

Fig. 2. Age-related changes in specific activities of alkaline phosphatase (ALP: A) and $\gamma$-glutamyl transpeptidase $(\gamma$ GT: B) induodenal, jejunal, and ileal mucosal tissues of Wistar rats aged $2.5 \mathrm{wk}, 5 \mathrm{wk}, 5 \mathrm{mon}$, and $23 \mathrm{mon}$. Each value notes mean \pm S.E.M for groups of 8 rats.

the entire intestine. Specific activity of lactase at 2.5 wk of age was the highest along the entire intestine (Fig. 3C). In all age groups, significantly enhanced disaccharidase activities were observed in the jejunum and declined toward both the duodenum and ileum. Consequently, a well developed structure of microvilli and the highest specific activities of BBM enzymes were obtained in Wistar rats at 5 mon of age.

\section{Discussion}

From our observations, rats aged 23 mon had decreased total mucosal cell weight, although total intestinal weight and length were significantly increased with age. This discrepancy was probably due to in-
$\mathbf{A}$

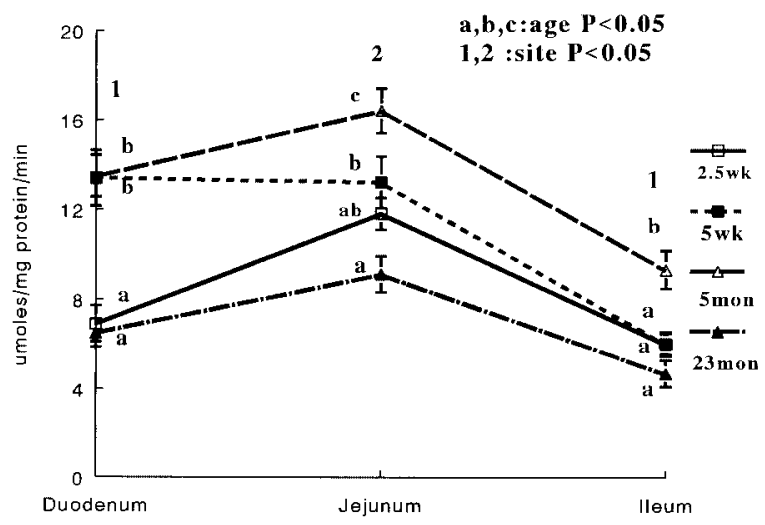

B

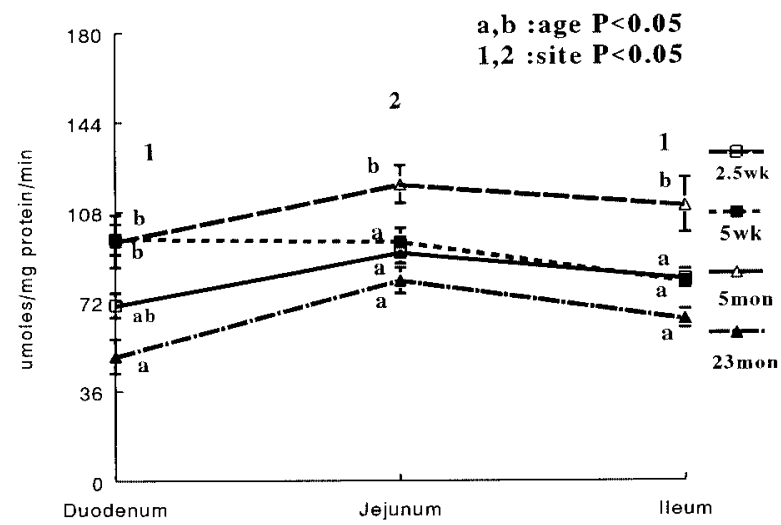

C

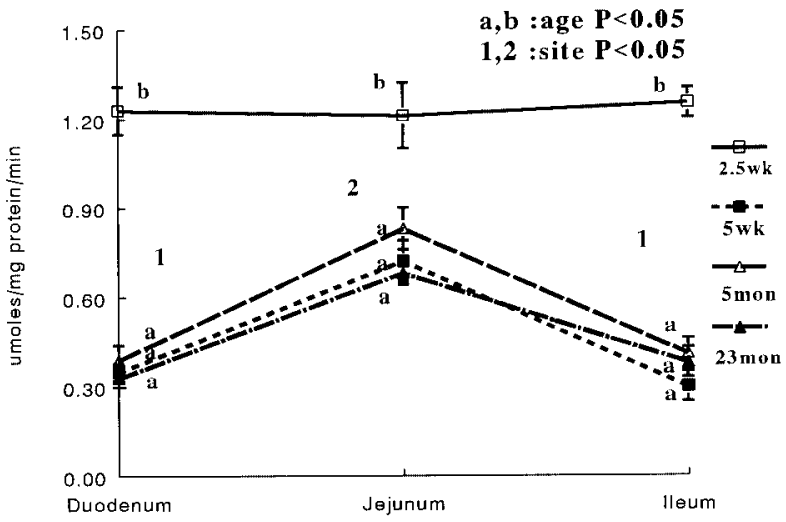

Fig. 3. Age-related changes in specific activities of disacchridase (sucrase: A, maltase: B, and lactase: C) in duodenal, jejunal, and ileal mucosal tissues of Wistar rats aged $2.5 \mathrm{wk}, 5$ wk, 5 mon and 23 mon. Each value notes mean \pm S.E.M for groups of 8 rats.

creased non-cellular connective tissue (collagen and reticular fibers), smooth muscle (lamina propia and muscularis mucosae), and residual fat in the small intestine of 23-mon-old rats. 
We also tried to obtain valuable information about the structural features of absorptive cells with age. Although the morphological structure of absorptive cells has been studied in rats [31], mice [28], rabbit [21], guinea pig [7] and monkeys [22] under various environmental circumstances so far, few studies have investigated age-related changes in intestinal microvilli structure. The structure of absorptive cells in the small intestine was influenued by environmental conditions such as nutrients [24], diabetes [31] and microbes [28]. The tall and columnar absorptive cells are covered with microvilli. The microvilli are directly responsible for an increase in the surface area of absorptive cells of about 15- to 40-fold and BBM enzymes including ALP, $\gamma$-GT, and disaccharidase are located on them [1]. The intestinal villi of the germ free mouse were short and slender but the crypt was shallow, although the total absorptive area of the germ free mouse was known to be decreased [24]. An extrusion of intestinal epithelial cells occurred under enteric infection by various microbes [28]. As shown in Fig. 1, apparently the microvillus membrane of absorptive cells from 23-mon-old rats was impaired and less dense than that from 5-mon-old rats, but a study has described quite normal ultrastructure of jejunal villi in aged mice, except that mitochondria were somewhat irregularly enlarged in aged mice [20].

The increase in transporter protein was closely related to increasing site density in the BBM from lamb [27]. With age, the function of absorbing nutrients such as amino acids and glucose in the proximal intestine was impaired in aged mice [9]. The impaired structure of microvilli in 23-mon-old rats which we observed could result in reduced absorption of nutrients. This less dense structure of microvilli was presumably correlated with declined activities of BBM enzymes located on the BBM of the small intestine. Expression of intestinal enzymes originating in the BBM of the absorptive cells in the small intestine was affected by age [17]. The ALP, an important constituent of the microvillus membrane may be involved in dephosphorylation, synthesis of cellular protein, differentiation of the cell, and glycosylation of membrane $[19,20]$. Because intestinal ALP activity and the level of mRNA in rats had increased by day 22-24 after birth [30], this could explain the decreased activity in 2.5-wk-old rats which we observed. When comparing the ALP activity in 6-mon- and 34-mon-old
BDF1 mice, activity in the older mice had decreased about 50\% [25]. As regards intestinal sites, the duodenum of mice had almost 10-fold greater ALP activity than the ileum. The distribution of ALP activity in mice, rabbits, sheep and monkeys along the intestine $[3,6,16]$ was similar to that in rats observed in this trial. $\gamma$-GT, one of the carboxypeptidases and a constituent of the microvilli responsible for the digestion of peptides, enhanced its activity in response to increasing dietary protein, carbohydrate or sucrose levels [8]. There were few data available on age-dependent development of $\gamma$-GT in rats. As regards regions, the specific activity of $\gamma$-GT along the intestine declined steeply from the duodenum to the ileum in this trial. But it was reported concerning mice that $\gamma$-GT activity along the small intestine peaked in the jejunum $[8,12]$. Decreased activities of sucrase and maltase in rats aged $2.5 \mathrm{wk}$ indicated that the function of BBM had not developed well enough to digest carbohydrate. And reduced disaccharidase activities in aged rats observed in our results and another study [17] might be associated with impaired structure of microvilli. There are a lot of factors involved in developing the activities of disaccharidase during the postnatal period. The involvement of EGF, thyroxine and secretin in postnatal maturation of intestinal sucrase, lactase and maltase are known $[11,15,26]$. Dietary fiber also induced development of maltase in suckling animals [14, 29]. As expected, lactase specific activity was very high during suckling, but weaning had a dramatic effect, with a sharp decline in lactase activity. As regards the intestinal region, specific activities of sucrase, maltase and lactase were greatest in the upper-middle jejunum of rats and declined toward both the duodenum and ileum $[18,19]$, whereas in the pre-weaning, evenly distributed lactase activity was maintained along the entire intestine. In conclusion, changes in age significantly affected the structure of BBM and the levels of intestinal BBM enzyme activities, as well as the mass of the mucosae, although enormous modulation of intestinal function occurred at weanling.

\section{References}

1. Argenzio, R.A. 1989. Digestive absorption of Carbohydrate, fat, and protein. pp. 301-310. In: M.J. Swenson (2nd Ed.) Duke's Physiology of Domestic Animals. Cornell University press, Ithaca, New York. 
2. Argiles, J.M. and Lopez-Soriano, F.J. 1990. Intestinal amino acid uptake along rat small intestine Biochem. Biophys. Acta 225: 315-325.

3. Brown, P.D. and Sepulveda, F.V. 1985. A rabbit jejunal isolated enterocyte preparation suitable for transport studies. J. Physiol (Lond.). 363: 257-270.

4. Buddington, R.K. 1994. Nutrition and ontogenic development of the intestine. Can. J. Physiol. Pharmacol. 72: 251-259.

5. Dahlgvist, A. 1968. Assay of the intestinal disaccharidase. Anal. Biochem. 22: 99-107.

6. Dhaunsi, G.S., Sidhu, G.S., Garg, U.C., Singh, Y., Chakravarti, R.N., and Bhatnagar, R. 1989. Effects on intestinal nutrient uptake and brush border membrane enzymes in response to atherogenic diets in rhesus monkeys. J. Med. Primatol. 18: 467-475.

7. Dullo, R.M., Majumdar, S., Chakravarti, R.N., and Mahmood, A. 1982. Intestinal brush border membrane structure and function: effects of chronic vitamin C deficiency in guinea pigs. Biochem. Med. 27: 325-353.

8. Ferraris, R.P., Villenas, S.A., and Diamond, J.M. 1992. Regulation of brush border enzyme activities and enterocyte migration in mouse small intestine. Am. J. Physiol. 262: G1047-G1059.

9. Ferraris, R.P. and Vinnakota, R.R. 1993. Regulation of Intestinal nutrient transport is impaired in aged mice. $J$. Nutr. 123: 502-511.

10. Ferraris, R.P. and Vinnakota. R.R. 1995. The time course of adaptation of intestinal nutrient uptake in mice is independent of age. J. Nutr. 125: 2172.

11. Foltzer-Jourdainne, C., Garaud, J.C., Nsi-Emvo, E., and Raul, F. 1993. Epidermal growth factor and the maturation of intestinal sucrase in suckling rats. Am. J. Physiol. 265: G459-G466.

12. Garvey, T.Q.III., Hymann, P.E., and Isselbacher, K.J. 1976. $\gamma$-Glutamyl transpeptidase of rat intestine: Localization and possible role in amino acid transport. Gastroenterology 71: 778-785.

13. Guo Z.M., Wang, G., Tian, J., Burger, M., Gocheld, M., and Yang, C.S. 1993. Age-and gender-related variations in the activities of drug-metabolizing and antioxidant enzymes in the white-footed mouse. Growth Dev. Aging 57: 85100.

14. Harada, E., Hashimoto, Y., and Syuto, B. 1995. Polydextrose induces precocious cessation of intestinal transmission and development of digestive enzymes in the suckling rats. Comp. Biochem. Physiol. Physiol. 111: 479485 .

15. Harada, E. and Syuto, B. 1993. Secretin induces precocious cessation of intestinal macromolecular transmission and maltase development in the suckling rats. Biol. Neonate. 63: 52-60.

16. Jang, I.S. 1993. Methionine and glucose transport by isolated intestinal brush border membrane vesicles from pigs and lambs fed an Aspergillus product. Dissertation, Virginia Polytechnic Institute and State University.
17. Lee M., Robert, M.R., and Montgomery, R.K. 1997. Total intestinal lactase and sucrase activities are reduced in aged rats. J. Nutr. 127: 1382-1387.

18. Maiuri, L., Rossi, M., Raia, V., Auria, S.D., Swallow, D., Quaroni, A., and Auricchio, S. 1992. Patch expression of lactase protein in adult rabbit and rat intestine. Gastroenterology 103: 1739-1746.

19. McCarthy, D.M., Nicholson, J.A., and Kim, Y.S. 1980. Intestinal enzyme adaptation to normal diets of different composition. Am. J. Physiol. 239: G445-G451.

20. Moog, F. 1977. The small intestine in old mice: Growth, alkaline phosphatase and disaccharidase activities, and deposition of amyloid. Exp. Geront. 12: 223-235.

21. Pang, K.Y., Bresson, J.L., and Walker, W.A., 1983. Development of the gastrointestinal mucosal barrier. Evidence for structural differences in microvillus membranes from new born and adult rabbits. Biochim. Biophys. Acta. 727: 201-208.

22. Paulini I., Mehta T., and Hargis, A., 1987. Intestinal structural changes in African green monkeys after long term psyllium or cellulose feeding. J. Nutr. 117: 253-266.

23. Quezada-Calvillo, R., Mqrkowitz, A.J., Traber, P.G., and Underdown, B.J. 1993. Murines intestinal disaccharidase: Identification of structural variants of sucrase-isomaltase complex. Am. J. Physiol. 265: 1141-1149.

24. Ruitenberg, E.J. and Peters, P.W. 1986. Laboratory Animals; Laboratory animal model for domestic animal production. Elsevier Science Publishers B.V. Armsterdam - Oxford - New York - Tokyo.

25. Sayeed, M. and Blumenthal, H.T. 1968. The small intestinal alkaline phosphatase activity in the old mouse. Proc. Soc. Exp. Biol. Med. 129: 1-10.

26. Shinder, D.A., Rakhimov, K.R., and Usmanova, O.D. 1995. Delay in natural decline of lactase activity in the small intestine of prematurely weaned rats as related to changes in their thyroid status. Comp. Biochem. Physiol. Physiol. (England) 111: 453-459.

27. Shirazi-Beechey, S.P., Smith, M.W., Wang, Y., and James, P.S. 1991. Postnatal development of Lamb intestinal digestive enzymes is not regulated by diet. J. Physiology (Lond.) 437: 691-698.

28. Takeuchi, A. and Hashimoto, K. 1976. Electron microscope study of experimental enteric adenovirus infection in mice. Infect. Immun. 13: 569-580.

29. Wild, G.E., Daly, A.S., and Bennett, G. 1993. Effect of exogenously administered polyamine on the structural maturation and enzyme ontogeny of the postnatal rat intestine. Biol. Neonate. 63: 246-257.

30. Yeh, K., Yeh, M., Holt, P.R., and Alpers, D.H. 1994. Development and hormonal modulation of postnatal expression of intestinal alkaline phosphatase mRNA species and their encoded isoenzymes. Biochem. J. 301: 893-899.

31. Zoubi, S.A., Mayhew, T.M., and Sparrow, R.A. 1995. The small intestine in experimental diabetes: cellular adaptation in crpts and villi at different longitudinal sites. Virchow Arch (Germany). 426: 501-507. 